Research Article

\title{
A Study on Assessment of Knowledge on Self-medication among the Students A Crossectional Study
}

\author{
Geeta Rawat* \\ Sunderdeep Pharmacy college, Sunder deep group of intuitions Ghaziabad Uttar Pradesh, India. \\ *Corresponding author's E-mail: geetarawat975@gmail.com
}

Received: 18-06-2021; Revised: 22-08-2021; Accepted: 25-08-2021; Published on: 15-09-2021.

\begin{abstract}
Self-medication is very frequent and common among the people. Several side effects have been reported to be associated with inappropriate use of self-medication like risk of drug dependence, abuse, major drug interactions and adverse effects. The aim of this study is designed to assess knowledge on self-medication among students. A cross-sectional study was conducted in students of various department located in Ghaziabad, UP, India. A total of 200 students were enrolled and interviewed using prevalidated questionnaire on self-medication. STATISTICAL ANALYSIS: Descriptive statistics were used to represent the sociodemographic characteristics and knowledge levels. Association of various socio-demographic variables with Knowledge levels are determined using the Chi-square test. A total of 200 students are recruited in these 53(26.5\%) diploma in pharmacy, 128 (64\%) bachelor's in pharmacy, $19(9.7 \%)$ master's in pharmacy. Among 200 respondents, 90 (45.2\%) good knowledge on self-medication. Subject's age, residential status, and occupation of their parents were significantly associated with knowledge and rational practice on self-medication with a $\mathrm{P}<0.05$.CONCLUSION: The study concludes there is lack of knowledge on responsible side effect of self-medication.
\end{abstract}

Keywords: knowledge, pharmacy students, practice, responsible self-medication.

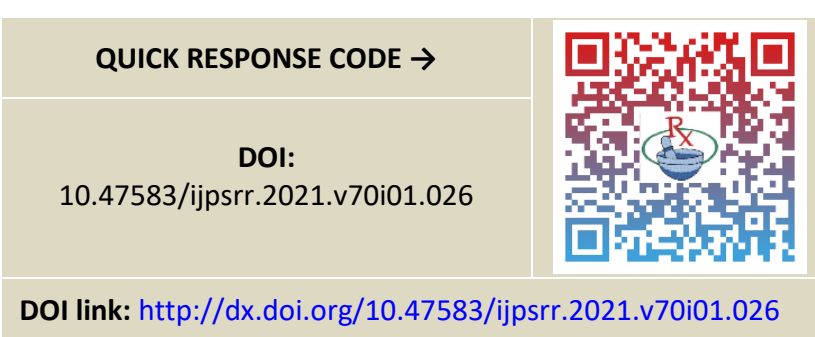

\section{INTRODUCTION}

S elf-medication is the treatment of common health issues with medicines especially designed and labeled for use without medical supervision. Selfmedication, which involves the selection and use of medicines to treat self-recognized symptoms. ${ }^{1}$ Medicines used for self-medication is often called nonprescription or over the counter drugs (OTC) for which no prescription is required in pharmacies. In countries like India not only OTC drugs, even prescription only medicines (POM) are also easily accessible without prescriptions in pharmacies ${ }^{2}$

Self-medication involves receiving medicines without prescriptions, using old drugs, sharing medicines with friends, relatives or others. These practices make irrational use of medicines which increases unwanted side effects ${ }^{3}$

The pattern of self-medication vary in the different subjects and are affected by various characteristics such as age, gender, income, self-care, literacy level, knowledge of medicines, previous experience, satisfaction, and illnesses type and condition. Schedule of students in pharmacy have understanding of drugs and their effects, but there was a lack of understanding of disease and its diagnosis. This knowledge regarding medicines uses among pharmacy student community will drive higher selfmedication practices, comparing to other medical and nonmedical students. Individuals are really influenced by the technology and get information about any drug and as well as they can buy drugs through websites, which results in irrational practice ${ }^{4}$.The study aims to assess the knowledge of responsible self-medication among students, UP,

\section{MATERIALS AND METHODS}

\section{Study design and participants}

Cross-sectional study, conducted in Pharmacy College of the university. The study was carried over a period of 6monthsfrom Aug 2018 to March 2019. Ethical clearance was taken from authorities before start of the study. Students enrolled in diploma, bachelor, and master in the pharmacy were included in this study. Students who are not willing to participate were excluded from this study.

\section{Sample size}

The sample size was calculated using Epi software Version 3.01.A pilot study was performed among 20 subjects to assess the feasibility and sample size. Based on the that, proportion of subjects having good knowledge about selfmedication were $4 \%$, respectively at confidence interval 95\%. Therefore, considering sample, 200 students were included in our study.

A total of 200 randomly selected eligible pharmacy students were given with a prevalidated self-administered questionnaire about responsible self-medication. The questionnaire comprises four parts to gather data regarding sociodemographic characteristics of the study 
population, Knowledge on self-medication. The sociodemographic details included are age, gender, level of education, religion, marital status, and family income.

\section{Knowledge on self-medication}

\section{Data analysis}

Statistical software was used to analyze collected data from all study participants. Descriptive statistics such as mean, standard deviation, frequency, and proportion were used to represent the sociodemographic characteristics and Knowledge level of the subject. Association of sociodemographic variables with Knowledge levels is determined using Chi-square test. $\mathrm{P}<0.05$ was considered as statistically significant.

\section{RESULTS}

200 pharmacy students are responded to self-medication questionnaire, in which most 178 (89\%) of the students were between 20 and 24 years of age. more than half of the students are boys 168 (80\%). Most of the responded pharmacy students are pursuing bachelor's in pharmacy $160(80 \%)$ and diploma of pharmacy 40 (20). Majority of the participants were from rural residency.

Table 1: Details of Sociodemographic profile $(n=200)$

\begin{tabular}{|c|c|c|c|}
\hline Characteristics & Frequency & Percentage & P-value \\
\hline \multicolumn{4}{|l|}{ Age } \\
\hline $19-22$ & 10 & 5 & \multirow{4}{*}{0.008} \\
\hline $22-25$ & 178 & 89 & \\
\hline $25-28$ & 10 & 5 & \\
\hline $28>$ & 2 & 1 & \\
\hline \multicolumn{4}{|l|}{ Programmane } \\
\hline B. Pharmacy & 160 & 80 & \multirow[t]{2}{*}{0.298} \\
\hline D. Pharmacy & 40 & 20 & \\
\hline \multicolumn{4}{|l|}{ Gender } \\
\hline Male & 158 & 79 & \multirow[t]{2}{*}{0.364} \\
\hline Female & 42 & 21 & \\
\hline \multicolumn{4}{|l|}{ Residential area } \\
\hline Rural & 145 & 72.5 & \multirow[t]{2}{*}{0.296} \\
\hline Urban & 55 & 27.5 & \\
\hline \multicolumn{4}{|c|}{ Parent' Profession } \\
\hline Farmer & 49 & 24.5 & \multirow{5}{*}{0.863} \\
\hline Govt employee & 58 & 29 & \\
\hline Business & 68 & 34 & \\
\hline Others & 24 & 12 & \\
\hline No response & 1 & 0.5 & \\
\hline
\end{tabular}

Among 200 respondents 140 (70\%) were not aware about the definition of self-medication. More than half of the students are not aware about the correct dosage regimen for particular illness. The majority 122 (61.3\%) of the students were not aware of illnesses in which selfmedication is advisable. Very less number of students are having knowledge regarding drugs, dosage, and course of medicine for self-medication. Knowledge on selfmedication among pharmacy students $(n=200)$

Table 2 : Source of medication

\begin{tabular}{|c|c|c|}
\hline & N(FREQUENCY) & $\%$ \\
\hline Pharmacy /clinic & 32 & $16 \%$ \\
\hline Friends & 30 & $15 \%$ \\
\hline Stock at home & 28 & $14 \%$ \\
\hline Friends & 30 & $15 \%$ \\
\hline Others & 80 & $40 \%$ \\
\hline
\end{tabular}

Table 3: Take medicine without consulting doctor

\begin{tabular}{|c|c|c|}
\hline Frequent & N(frequency) & Percentage (\%) \\
\hline $\begin{array}{c}\text { Two or three times } \\
\text { in a year }\end{array}$ & 108 & $40 \%$ \\
\hline $\begin{array}{c}\text { Always } \\
\text { Once a year }\end{array}$ & 0 & $54 \%$ \\
\hline
\end{tabular}

Table 4: Symptoms leading to self-medication

\begin{tabular}{|c|c|c|}
\hline & $\mathbf{N}($ frequency) & $\%$ \\
\hline Fever & 38 & $19 \%$ \\
\hline Pain & 52 & 26 \\
\hline Cold/cough & 20 & 10 \\
\hline Diarrhea & 25 & $12.5 \%$ \\
\hline Menstrual pain & 10 & $5 \%$ \\
\hline Constipation & 6 & $3 \%$ \\
\hline Heartburn/indigestion & 18 & $9 \%$ \\
\hline Weight loss & 3 & $1.5 \%$ \\
\hline Vomiting & 28 & $14 \%$ \\
\hline
\end{tabular}

Table 5 : Reason for practicing self-medication

\begin{tabular}{|c|c|c|}
\hline Problem was not severe & N (frequency) & $\%$ \\
\hline $\begin{array}{c}\text { Previous experience } \\
\text { Urgency of medical } \\
\text { condition }\end{array}$ & 18 & $9 \%$ \\
\hline Availability & 88 & $3 \%$ \\
\hline $\begin{array}{c}\text { Lack of time } \\
\text { Advice from friend/ } \\
\text { relative }\end{array}$ & 26 & $44 \%$ \\
\hline
\end{tabular}

Table 6: Common medication advice to health issues?

\begin{tabular}{|c|c|c|}
\hline & $\mathbf{N}($ frequency) & $\%$ \\
\hline Anti-diarrheal & 28 & $14 \%$ \\
\hline Anti-allergic & 20 & $10 \%$ \\
\hline Vitamins & 20 & $10 \%$ \\
\hline Antibiotic & 39 & $19.5 \%$ \\
\hline Contraceptives & 28 & $14 \%$ \\
\hline Cold \& flu medication & 25 & $12.5 \%$ \\
\hline Analgesic and & 40 & $20 \%$ \\
\hline Antipyretic & & \\
\hline
\end{tabular}


Table 7: Knowledge and Awareness level of students on self-medication (chi-square test, $* P<0.05$ significant)

\begin{tabular}{|r|c|c|c|}
\hline Questionnaire & Yes & No & P-value \\
\hline Awareness level of students on self-medication & $90(45)$ & $110(55)$ & 0.028 \\
\hline Are you aware of the side effects of those medication? & $40(20)$ & $160(80)$ & 0.038 \\
\hline Are you aware of the dose & $19(9.5)$ & $181(90.5)$ & 0.291 \\
\hline Are you aware of the adverse drug reactions? & $55(27.5)$ & $145(72.5)$ & 0.027 \\
\hline Are you aware about the expiry date? & $194(97)$ & $6(3)$ & 0.639 \\
\hline Are aware of illnesses in which self-medication is advisable. & $128(64$ & $72(36)$ & 0.561 \\
\hline
\end{tabular}

\section{DISCUSSION}

Self-medication is the practice of individuals when they treat their ailments and illnesses with drugs which are available without prescription. ${ }^{7}$ However, it will cause adverse effects if unnecessarily used. Hence, awareness level on self-medication among pharmacy students is important for promoting health and to reduce druginteractions and side effects this study focuses on selfmedication among pharmacy students The study only 80 (40\%) of the students are aware about self-medication. Pains, headache, cold, fever, diarrhea, vomiting, and cramps are most common types of health issues where students will opt self-medication. ${ }^{9}$ The similar type problems are also reported in the previous study conducted by Sawalha among Palestinian students. ${ }^{10}$ .excessive use of antibiotic self-medication requires special emphasis. This practice causing major issues like antibiotic resistance ${ }^{12}$.need is to educate students on antibiotic use and their risk of microbial resistance. There is a need to concentrate on rational usage of antibiotics. ${ }^{13}$

Most of the students gain knowledge by consulting physician (38.7\%) and pharmacist (28.8\%), some of the students are using knowledge about self-medication from previous experience and previous prescriptions, this information may lead to irrational self-medication practice. In this study, the major reasons for selfmedications include quick relief $(42.4 \%)$ and no need to visit doctor for minor illness (37.5\%). This may be due to pharmacy students have better knowledge about drugs, so have less predisposition to seek physicians help to treat their illness. The same findings are also mirrored in the study conducted by Bollu et al., among pharmacy students in Guntur. ${ }^{14}$ Most of the students are getting selfmedication information by consulting pharmacist. There is a necessity to train all community pharmacists about responding to minor illnesses and avoiding nonprescription sale of prescription only drugs.

Maximum students have poor knowledge on selfmedication practice. Findings shows that there is need to conduct educational training programs about selfmedication. Paticipants age, their residential area, and their parents' profession were associated. The similar results were found $s$ in study conducted by Selvaraj et al. and Gandhi et al.15, 16 . Gender, religion, accommodation, and monthly household income are not associated with knowledge level on self-medication.

\section{CONCLUSION}

There was an overall positive response among students on self-medication. The results show that level of awareness on self-medication concept among students is lower in students coming from rural background as compared to urban background students .use of self-medicated drugs is high in both rural and urban background students .there is need of the hour to let people know about the side effects adverse effects of the self-medication through seminars, workshops, and other activities to improve knowledge and practice and it will have a good influence on the rational use of nonprescription (OTC) drugs

\section{REFERENCES}

1. Badiger S, Kundapur R, Jain A, Kumar A, Pattanshetty S, Thakolkaran N, et al. Self-medication patterns among medical students in South India. Australas Med J. 2012; 5: 217-20.

2. Pereira FS, Bucaretchi F, Stephan C, Cordeiro R. Selfmedication in children and adolescents. J Pediatr (Rio J) 2007; 83: 453-8.

3. Hansen $E H$, Holstein BE, Due $P$, Currie CE. International survey of self-reported medicine use among adolescents. Ann Pharmacother. 2003; 37: 361-6.

4. Venkataraman G, Gangadharappa SK, Jacob J, Bhaskar N, Kulkarni SB, Gupta A. Assessment of self-medication practice among students at a dental college of Bangalore city: A cross-sectional study. J Indian Assoc Public Health Dent. 2017; 15: 73-7.

5. McPartland TS, Weaver BA, Lee SK, Koutsky LA. Men's perceptions and knowledge of Human Papilloma Virus (HPV) infection and cervical cancer. J Am Coll Health. 2005; 53: 225-30.

6. Leyva M, Byrd T, Tarwater P. Attitude towards cervical cancer screening: A study of beliefs among women in Mexico. Calif J Health Promot. 2006; 4: 13-24.

7. Gyawali S, Shankar PR, Poudel PP, Saha A. Knowledge, Attitude and Practice of Self-Medication among Basic Science Undergraduate Medical Students in a Medical School in Western Nepal. J Clin Diagn Res. 2015; 9: FC1722

8. Gupta S, Singh M. Self-medication among North Indian first-year undergraduate healthcare students: A 
questionnaire-based study. Trop J Med Res. 2016; 19: 1627.

9. Kumar A, Vandan A, Aslami AN. Analgesics Self-Medication and its Association with Sleep Quality among Medical Undergraduates. J Clin Diagn Res. 2016; 10: FC07-11.

10. Sawalha AF. A descriptive study of self-medication practices among Palestinian medical and nonmedical university students. Res Social Adm Pharm. 2008; 4: 16472.

11. Verma RK, Mohan L, Pandey M. Evaluation of selfmedication among professional students in North India: Proper statutory drug control must be implemented. Asian J Pharm Clin Res. 2010; 3: 60-4.

12. Morgan DJ, Okeke IN, Laxminarayan R, Perencevich EN, Weisenberg $S$. Non-prescription antimicrobial use worldwide: A systematic review. Lancet Infect Dis. 2011; 11: 692-701
13. Radyowijati A, Haak H. Improving antibiotic use in lowincome countries: An overview of evidence on determinants. Soc Sci Med. 2003; 57: 733-44

14. Bollu M, Vasanthi B, Chowdary PS, Chaitanya DS, Nirojini PS, Nadendla RR. Prevalance of self-medication among the pharmacy students in Guntur: A questionnaire-based study. World J Pharm Pharm Sci. 2014; 3: 810-26.

15. Selvaraj K, Kumar SG, Ramalingam A. Prevalence of selfmedication practices and its associated factors in Urban Puducherry, India. Perspect Clin Res. 2014; 5: 32-6.

16. Gandhi S, Gandhi RA, Nayyar AS. Assessment of abuse of self-medication for oral and dental problems among 21-60 year saged populace residing in the rural areas of Belgaum Taluk, Karnataka, India: A questionnaire study. Arch Med Health Sci. 2016; 4: 180-4.

Source of Support: The author(s) received no financial support for the research, authorship, and/or publication of this article.

Conflict of Interest: The author(s) declared no potential conflicts of interest with respect to the research, authorship, and/or publication of this article.

For any question relates to this article, please reach us at: editor@globalresearchonline.net New manuscripts for publication can be submitted at: submit@globalresearchonline.net and submit_ijpsrr@rediffmail.com 